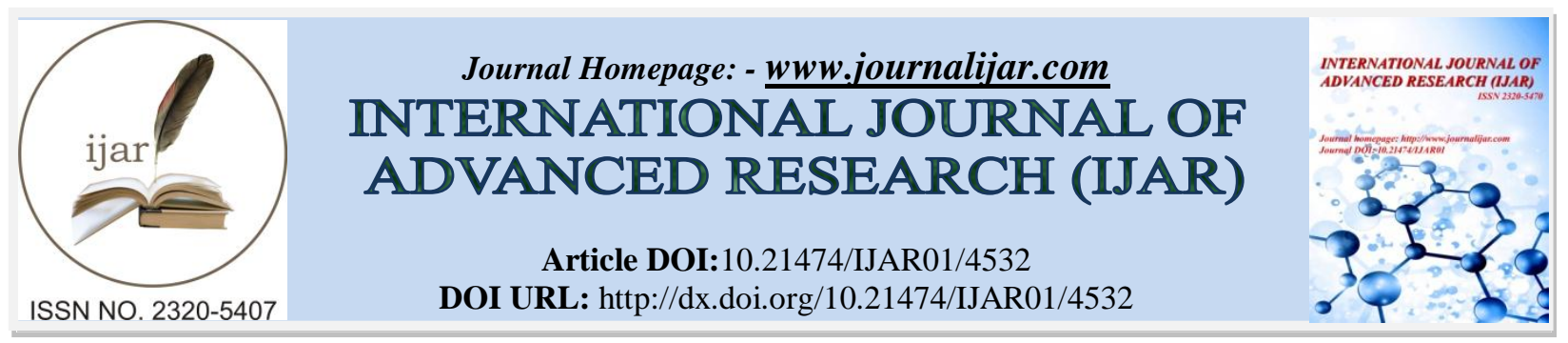

RESEARCH ARTICLE

\title{
EFFECT OF TRADITIONAL AGRONOMIC PRACTICES ON FUNGAL DISEASES OF RAPESEED - MUSTARD UNDER ORGANIC FARMING SYSTEM IN MANIPUR.
}

Yengkhom Premlata Devi and G.K.N. Chhetry.

Department of Life Sciences, Manipur University ,Canchipur, Imphal - 795003, India

\section{Manuscript Info}

\section{Manuscript History}

Received: 19 April 2017

Final Accepted: 21 May 2017

Published: June 2017

Key words:-

Agronomic practices, fungal diseases, weather variables.

\section{Abstract}

Field experiments were conducted at Kakching, Manipur to test the effect of traditional agronomic practices (intercropping, plant density and date of sowing) on fungal diseases of rapeseed -mustard i.e., two varieties of rapeseed and two local cultivars of mustard during rabi $2014-15 \& 2015-16$. Correlation of weather parameters with disease severity of Alternaria blight was carried out to evaluate the nature of disease progress. The crop was raised under organic condition using normal agronomic practices followed by organic farmers of the area. Weekly surveys for quantification of diseases revealed significant effects of the agronomic practices on severity of fungal diseases . Although all the agronomic practices were effective, plant density $\left(\mathrm{T}_{3}\right)$ was found to be most effective in reducing the disease severity of the crop. Weather variables play important roles in disease development.

Copy Right, IJAR, 2017,. All rights reserved.

\section{Introduction:-}

Rapeseed and mustard are one of the most important cruciferous crops which are grown basically for oil and vegetable during rabi season in Manipur. The crop was infested by many diseases prominently fungal diseases which cause limitation in the productivity of the crop. More than 30 diseases including fungal diseases were known to occur on Brassica crops in India Saharan (1992). In India, yield losses due to Alternaria blight was reported to be $15-71 \%$ ( Kaidan and Saharan, 1983). The local and leaf phase infection of white rust caused yield losses of 23 - 54.5\% ( Saharan et al., 1984). Changes in cultivation practices, weather variables and virulence of the pathogen may contribute to high disease severity. As such powdery mildew a minor disease earlier has become a major one ( Bhander et al., 1963). Depending upon the variety used the average losses due to powdery mildew has been observed to be $19-29.5 \%$ ( Mehta et al., 2008). Management of diseases using synthetic chemicals resulted harmful effects on environment, soil and human health by virtue of biomagnification in subsequent trophic levels.

Barbetti (1981) reported that disease escape is one of the principles in the management of diseases. For this we may apply many traditional agronomic practices to avoid diseases from time to time. As management of diseases through agronomic practices play important roles basically due to its easy adoption, low cost and eco-friendly, it necessitates an urgent need to find out suitable agronomic practices to avoid the crop from various fungal diseases. However, such study was not investigated under organic farming system in the study site. As such with the view of developing disease management strategies of the crop which are cost effective, eco-friendly and of wider application the present work was conducted to observe the influences of intercropping, plant spacing and date of sowing under organic farming system in Manipur. 


\section{Materials and Methods :-}

Field experiments were conducted at Kakching located in $24^{\circ} 29^{\prime} 30^{\prime \prime} \mathrm{N}$ latitude and 93'59' 30" E longitude and about $45 \mathrm{~km}$ away from Imphal, Manipur for two consecutive rabi seasons (2014-15 \& 2015-16) to evaluate the effect of intercropping, plant density and date of sowing. The experimental varieties are two rapeseed varieties [ Brassica. rapa (L.) var. M27 $\left(\mathrm{V}_{3}\right)$ andB. rapa (L.) var. ragini $\left(\mathrm{V}_{4}\right)$ ] and two local cultivars of mustard [B. juncea (L.) Czern. \& Coss. cv. Local Yella $\left(\mathrm{V}_{1}\right)$ and B. juncea Czern. \& Coss. cv. Lamtachabi $\left(\mathrm{V}_{2}\right)$ ]. The correlation of weather parameters (crop season) with disease severity of Alternaria blight on different sowing dates were also found out to understand the nature of disease progress. The weather data were obtained from Rice Research Station, Wangbal under Thoubal distict, Manipur. The experimental field has an earlier record of growing seasonal vegetables including mustard. Proper treatments were done to evaluate different agronomic practices applied. Seeds were sown in the last week of October except for date of sowing experiment in plots [(2.2 x 1.3$\left.) \mathrm{m}^{2}\right]$ keeping some border line with three replications. For date of sowing ( DOS) experiment seeds were sown on five different dates viz., 30.09.14( $\left.\mathrm{D}_{1}\right), 15.10 .14\left(\mathrm{D}_{2}\right), 30.10 .14\left(\mathrm{D}_{3}\right), 14.11 .14\left(\mathrm{D}_{4}\right)$ and $29.11 .14\left(\mathrm{D}_{5}\right)$ by maintaining 15 days interval which started from September to November. A spacing of $(30 \mathrm{x} 10) \mathrm{cm}^{2}$ with row to row and plant to plant were maintained except for the plant density field experiment. For plant density, three treatments by making different spacing viz., $\mathrm{T}_{1}=(20 \times 5) \mathrm{cm}^{2}, \mathrm{~T}_{2}=(30 \mathrm{X} \mathrm{10}) \mathrm{cm}^{2}$ and $\mathrm{T}_{3}(40 \mathrm{X} \mathrm{15}) \mathrm{cm}^{2}$ were done to evaluate their effects on major fungal diseases such as white rust, Alternaria blight and Powdery mildew severity of rapeseed mustard. A ratio of 5:1 with rapeseed and pea ( Pisum sativum L.) and 3:1 with mustard and pea were also raised for observing intercropping effect with pea. The crop was laid out in a randomized block design (RBD) under irrigated condition using farmyard manure (FYM). Weeding, irrigation and other cultural practices were done during the growing period in both the seasons.

A weekly survey was conducted at 45 days after sowing (DAS) for white rust and Alternaria blight of the crop. For powdery mildew at 55 and 90 DAS in rapeseed and mustard respectively. Six survey schedules were done starting from November to March in each year. Data on disease severity (DS) of rapeseed- mustard were recorded from 25 leaves randomly selected from 5 plants in each plot after appearance of disease and tagged. Diseases were rated using 0-6 scale for white rust ( Barbetti et al., 2011), 0-5 scale for Alternaria blight ( Awasthi and Kolte, 1994) and 0-5 scale for powdery mildew( Singh and Singh , 2003). Disease severity data were statistically analyzed using one way ANOVA and t-test to evaluate any variance and significance of white rust, Alternaria blight and powdery mildew severity among the various treatments of agronomic practices. MS - Excel and SPSS (v. 21) were used for computation of the data.

\section{Results and Discussion:-}

Experiments on various agronomic practices during the two consecutive rabi seasons ( $2014-15$ \& 2015 -16) revealed significant effects on white rust, Alternaria blight and powdery mildew severity of rapeseed - mustard. Intercropping of the crop with pea provided significant effects on disease severity than sole cropping ( Table:- 1). It may be contributed that intercropping assists to avoid inter- crop competition and hence a large number of crops can be grown per unit area at a time which enables efficient resource utilization and increased productivity probably by minimizing disease level. Moreover, intercropping provides shading effect which might outfit physical stress to the crop. The present finding corroborated with the findings of previous workers ( Gomez- Rodriguez et al., 2003) who reported that appropriate intercropping systems are more favorable to control diseases without chemicals comparing with monoculture. Similar outcomes were also reported by other workers ( Abdel - Monaim and Abo - Elyousr, 2012) in other crop.

Plant density treatments provided significant effects on white rust, Alternaria blight and powdery mildew of the crop ( Table: - 2). By virtue of different plant spacing in plant density treatments the number of plants varies i.e.inT ${ }_{1}(240$ plants), $\mathrm{T}_{2}$ ( 84 plants ) and $\mathrm{T}_{3}$ (40 plants). The degree of disease severity were found increased in $\mathrm{T}_{1}$ while reduced in $\mathrm{T}_{3}$ than $\mathrm{T}_{2}$. It may be attributed that more nutrient uptake and utilization for proper growth of the crop was facilitated by enough space availability around the crop. More or less similar findings that reduction in spacing between plants increased the incidence of seed borne infection in rice (Agarwal et al., 1975).

Statistically, significant variances were resulted among the treatments of date of sowing on different fungal diseases of rapeseed - mustard (table:- 3). Highest disease severity in white rust $\left(18.08 \%-\mathrm{V}_{2}\right)$, Alternaria blight (17.10\% $\mathrm{V}_{2}$ ) and powdery mildew $\left(40.43 \%-\mathrm{V}_{2}\right)$ were found in the crop sown on 29.11.2014. Sowing of rapeseed- mustard varieties earlier than 30.10 .2014 resulted less disease severity even though there was some fluctuations in $\mathrm{D}_{2}$ 
Table 1:- Effect of intercropping on disease severity of three foliar fungal diseases of rapeseed - mustard at Kakching ( experimental site) during rabi 2014- 2015 \& 2015- 2016 ( Pooled for two years).

\begin{tabular}{|l|l|l|l|l|l|l|l|l|l|l|l|l|}
\hline \multirow{2}{*}{ Treatments } & \multicolumn{4}{|l|}{ White rust } & \multicolumn{4}{l|}{ Alternaria blight } & \multicolumn{4}{l|}{ Powdery mildew } \\
\cline { 2 - 13 } & $\mathrm{V}_{1}$ & $\mathrm{~V}_{2}$ & $\mathrm{~V}_{3}$ & $\mathrm{~V}_{4}$ & $\mathrm{~V}_{1}$ & $\mathrm{~V}_{2}$ & $\mathrm{~V}_{3}$ & $\mathrm{~V}_{4}$ & $\mathrm{~V}_{1}$ & $\mathrm{~V}_{2}$ & $\mathrm{~V}_{3}$ & $\mathrm{~V}_{4}$ \\
\hline Intercropping & 14.31 & 15.33 & 12.80 & 12.29 & 16.57 & 14.01 & 11.75 & 11.90 & 33.12 & 37.79 & 15.68 & 16.50 \\
\hline Control & 16.32 & 17.29 & 14.99 & 14.81 & 18.54 & 17.70 & 12.52 & 13.02 & 36.66 & 40.46 & 16.54 & 19.19 \\
\hline *t-value (5\%) & 7.02 & 9.02 & 15.98 & 10.34 & 5.09 & 8.27 & 5.70 & 3.21 & 3.32 & 13.06 & 13.53 & 17.66 \\
\hline
\end{tabular}

Treatment and control data are mean of six observations in each year ; *Significant at $5 \%$ level of significance.

Table 2:- Effect of plant density on disease severity of three foliar fungal diseases of rapeseed - mustard at Kakching during rabi 2014- 2015 \& 2015- 2016 ( Pooled for two years).

\begin{tabular}{|l|l|l|l|l|l|l|l|l|l|l|l|l|}
\hline \multirow{2}{*}{ Treatments } & \multicolumn{4}{|l|}{ White rust } & \multicolumn{4}{|l|}{ Alternaria blight } & \multicolumn{3}{l|}{ Powdery mildew } \\
\cline { 2 - 14 } & $\mathrm{V}_{1}$ & $\mathrm{~V}_{2}$ & $\mathrm{~V}_{3}$ & $\mathrm{~V}_{4}$ & $\mathrm{~V}_{1}$ & $\mathrm{~V}_{2}$ & $\mathrm{~V}_{3}$ & $\mathrm{~V}_{4}$ & $\mathrm{~V}_{1}$ & $\mathrm{~V}_{2}$ & $\mathrm{~V}_{3}$ & $\mathrm{~V}_{4}$ \\
\hline $\mathrm{T}_{1}$ & 16.01 & 16.25 & 12.90 & 12.14 & 16.93 & 14.95 & 11.37 & 10.75 & 37.59 & 41.28 & 16.92 & 20.06 \\
\hline $\mathrm{T}_{2}$ & 14.04 & 14.84 & 11.63 & 10.86 & 12.97 & 12.84 & 9.41 & 9.19 & 35.32 & 37.84 & 16.06 & 18.00 \\
\hline $\mathrm{T}_{3}$ & 11.03 & 12.70 & 10.47 & 9.57 & 11.08 & 11.97 & 9.42 & 7.86 & 33.21 & 35.81 & 15.08 & 17.10 \\
\hline *C.D.(5\%) & 0.37 & 0.37 & 0.51 & 0.36 & 0.60 & 0.48 & 0.29 & 0.37 & 0.37 & 0.74 & 0.35 & 0.60 \\
\hline
\end{tabular}

*Significant at $5 \%$ level of significance.

Table 3:- Effect of date of sowing on disease severity of three foliar fungal diseases of rapeseed - mustard at Kakching during rabi 2014- 2015 \& 2015- 2016 ( Pooled for two years).

\begin{tabular}{|l|l|l|l|l|l|l|l|l|l|l|l|l|l|}
\hline \multirow{2}{*}{ Treatments } & \multicolumn{4}{l|}{ White rust } & \multicolumn{4}{l|}{ Alternaria blight } & \multicolumn{4}{l|}{ Powdery mildew } \\
\cline { 2 - 16 } & $\mathrm{V}_{1}$ & $\mathrm{~V}_{2}$ & $\mathrm{~V}_{3}$ & $\mathrm{~V}_{4}$ & $\mathrm{~V}_{1}$ & $\mathrm{~V}_{2}$ & $\mathrm{~V}_{3}$ & $\mathrm{~V}_{4}$ & $\mathrm{~V}_{1}$ & $\mathrm{~V}_{2}$ & $\mathrm{~V}_{3}$ & $\mathrm{~V}_{4}$ \\
\hline $\mathrm{D}_{1}$ & 12.97 & 14.54 & 11.30 & 11.06 & 13.01 & 13.01 & 11.13 & 9.84 & 34.73 & 36.99 & 15.99 & 15.73 \\
\hline $\mathrm{D}_{2}$ & 13.75 & 14.80 & 11.43 & 11.68 & 13.94 & 14.44 & 11,66 & 12.06 & 35.54 & 38.41 & 16.77 & 17.94 \\
\hline $\mathrm{D}_{3}$ & 13.45 & 13.80 & 11.82 & 11.55 & 14.97 & 15.21 & 12.97 & 12.73 & 36.17 & 38.97 & 17.66 & 18.75 \\
\hline $\mathrm{D}_{4}$ & 15.04 & 16.35 & 13.61 & 13.30 & 15.99 & 15.46 & 13.48 & 13.26 & 38.19 & 39.68 & 18.44 & 19.31 \\
\hline $\mathrm{D}_{5}$ & 17.74 & 18.08 & 12.71 & 11.75 & 16.63 & 17.10 & 12.72 & 12.72 & 38.84 & 40.43 & 18.75 & 20.02 \\
\hline *C.D.(5\%) & 0.15 & 0.18 & 0.29 & 0.22 & 0.42 & 0.38 & 0.36 & 0.38 & 0.51 & 0.56 & 0.38 & 0.38 \\
\hline
\end{tabular}

*Significant at $5 \%$ level of significance.

Table 4:- Effect of weather parameters on disease severity of Alternaria blight of rapeseed - mustard at different sowing dates at Kakching during rabi 2014- 2015 \& 2015- 2016 ( Pooled for two years) .

\begin{tabular}{|c|c|c|c|c|c|c|c|c|}
\hline \multirow[t]{2}{*}{ Date of sowing } & \multicolumn{4}{|c|}{ Disease severity (DS\%) } & \multirow{2}{*}{$\begin{array}{l}\text { Min. T } \\
\left({ }^{\circ} \mathrm{C}\right)\end{array}$} & \multirow{2}{*}{$\begin{array}{l}\text { Max.T } \\
\left({ }^{\circ} \mathrm{C}\right)\end{array}$} & \multirow{2}{*}{$\begin{array}{l}\text { RH } \\
(\%)\end{array}$} & \multirow{2}{*}{$\begin{array}{l}\text { Rainfall } \\
(\mathrm{mm})\end{array}$} \\
\hline & $\mathrm{V}_{1}$ & $\mathrm{~V}_{2}$ & $\mathrm{~V}_{3}$ & $\mathrm{~V}_{4}$ & & & & \\
\hline $30^{\text {th }}$ September & 13.01 & 13.01 & 11.13 & 9.84 & 15.67 & 22.06 & 84.32 & 0.62 \\
\hline $15^{\text {th }}$ October & 13.94 & 14.44 & 11.66 & 12.06 & 13.75 & 21.62 & 85.81 & 0.29 \\
\hline $30^{\text {th }}$ October & 14.97 & 15.21 & 12.97 & 12.73 & 12.86 & 21.53 & 84.77 & 1.16 \\
\hline $14^{\text {th }}$ November & 15.99 & 15.46 & 13.48 & 13.26 & 11.18 & 21.78 & 81.96 & 1.40 \\
\hline $29^{\text {th }}$ November & 16.63 & 17.10 & 12.72 & 12.72 & 10.36 & 22.10 & 75.56 & 1.13 \\
\hline \multicolumn{5}{|c|}{$\begin{array}{l}\text { Correlation coefficient }(\mathrm{r}) \text { with DS } \\
\mathrm{V}_{1} \\
\mathrm{~V}_{2} \\
\mathrm{~V}_{3}\end{array}$} & $\begin{array}{l}-0.98^{* *} \\
-0.95 * \\
-0.89 * \\
-0.93 *\end{array}$ & $\begin{array}{l}0.56(\mathrm{NS}) \\
0.38(\mathrm{NS}) \\
0.42(\mathrm{NS}) \\
0.14(\mathrm{NS})\end{array}$ & $\begin{array}{l}-0.93^{*} \\
-0.90^{*} \\
-0.64(\mathrm{NS}) \\
-0.60(\mathrm{NS})\end{array}$ & $\begin{array}{c}0.78(\mathrm{NS}) \\
0.68(\mathrm{NS}) \\
0.98 * * \\
0.92 *\end{array}$ \\
\hline
\end{tabular}

*Significant at $5 \%$ level of significance; **Significant at $1 \%$ level of significance;

Min.T = Minimum temperature $;$ Max.T $=$ Maximum temperature $; \mathrm{RH}=$ Relative humidity.

treatment in white rust if late, higher disease severity encountered. However, for rapeseed varieties disease severity first increased and then reduced when sown late in case of white rust and Alternaria blight. These variations may be due to the fact that the rapeseed varieties mature earlier than mustard varieties hence congenial physiological stage of the crop was not available to infect in the former. However, for powdery mildew the disease severity values 
gradually increased in the varieties when sown late. It may be capability of the disease to infect in all parts of the plant such as leaves, stems and reproductive parts. So, early sown crops on 30.09.2014 than late sown can recede the crop from damages caused by white rust, Alternaria blight and especially powdery mildew. It is agree with the findings that the incidence of white rust, Alternaria blight of mustard was increased with delayed sowing ( Lakra and Saharan, 1989 ; Dasgupta et al., 1991). Similar findings that higher disease intensity under late sown conditions in rapeseed- mustard was reported by various authors ( Gupta et al., 2002 ).

In an overall assessment among the agronomic practices the least disease severity was detected in plant density $\left(7.86 \%-\mathrm{V}_{4}\right)$ followed by date of sowing $\left(9.84 \%-\mathrm{V}_{4}\right)$ and intercropping $\left(11.75 \%-\mathrm{V}_{2}\right)$ in Alternaria blight. Highest DS was found in date of sowing experiment under late sown conditions except some fluctuations in rapeseed for white rust and Alternaria blight diseases. In plant density $\left(\mathrm{T}_{3}\right)$ comparing with other treatments of agronomic practices the least DS were found for each fungal disease viz., white rust ( $9.57 \%$ ) in $\mathrm{V}_{4}$, Alternaria blight $(7.86 \%)$ in $\mathrm{V}_{4}$ and powdery mildew ( $\left.15.08 \%\right)$ in $\mathrm{V}_{3}$.

Negative correlations were found between Alternaria blight disease severity and minimum temperature (significant) and also with relative humidity which ranged from significant to non - significant. However, positive correlations were found between disease development and maximum temperature (non -significant) and also with rainfall which ranged from significant to non - significant ( Table:- 4). The present finding was more or less supported by various authors (Hedge and Anahosur, 1994; Saharan et al., 1988) who reported negative correlation with temperature and positive correlation with rainfall however, positive correlation with $\mathrm{RH}$ in disease development.

\section{Conclusion:-}

Weather parameters viz., minimum and maximum temperature, relative humidity and rainfall play important roles in epidemiology of Alternaria blight. Development of the disease was favoured by high temperature and rainfall with low temperature and relative humidity. Traditional agronomic practices particularly the plant density $\left(\mathrm{T}_{3}\right)$ were found effective in the management of white rust, Alternaria blight and powdery mildew under the organic farming system in Manipur's agro-climatic condition. These agronomic practices can provide economical, easy adoption, pollution free and sustainable management strategy for the rapeseed - mustard growers.

\section{Acknowledgement:-}

The Authors gratefully acknowledge Manipur University, Canchipur, Imphal for providing research fellowship and Rice Research Station, Wangbal for rendering the weather data.

\section{References:-}

1. Abdel-Monaim, M.F. and Abo-Elyousr, K.A.M. (2012): Effect of preceding and intercropping crops on suppression of lentil damping - off and root rot disease in New Valley - Egypt. Crop Prot., 32: 41-46.

2. Agarwal, V.K., Singh, O.V. and Modgal, S.C. (1975): Influence of different doses of nitrogen and spacing on seed- borne infection of rice. Indian Phytopath., 28: 38-40.

3. Awasthi, R.P. and Kolte, S.J. (1994): Epidemiological factors in relation to development and prediction of Alternaria blight of rapeseed and mustard. Indian Phytopath., 47, 395 - 399.

4. Barbetti, M.J., Li, C.X., Banga, S.S., Banga , S.K,. Sandhu ,P.S., Gurung, A. M. and Salisbury, P.A. (2011): High level resistance against white rust (Albugo candida) race 2V identified in Brassica juncea genotypes from China and Australia.13 ${ }^{\text {th }}$ International Rapeseed Congress June 5-9, Prague, Czech Republic.

5. Barbetti, M.J. (1981): Effects of sowing date and oospore seed contamination upon subsequent crop incidence of white rust (Albugo candida) in rapeseed. Austra. Plant Pathol., 10, $44-46$.

6. Bhander, D.S., Thakur, R.N. and Husain, A . (1963): Powdery mildew, a new disease of rapeseed and mustard in India. Plant Dis. Report. , 47, 1039.

7. Dasgupta, B., Ghosh, R.K . and Chatterjee, B.N. (1991): Effect of different dates and levels of nitrogen fertilizers on Alternaria blight disease and productivity of Indian mustard (Brassica juncea L.) Czern and Coss. Environ. Ecology, 9, $118-123$.

8. Gomez- Rodriguez, O., Zavaleta - Mejia, E., Gonzalez-Her nandez, V.A., Livera-Munoz M. and CardenasSoriano, E. (2003): Allelopathy and microclimatic modification of intercropping with marigold on tomato early blight disease development. Field Crops Res., 83: 27-34.

9. Gupta, K., Saharan, G.S. and Singh, D. (2002): Assessment of white rust severity on Brassica juncea under genotype-environment interactions. J Mycol Pl Pathol., 32 : 106-109. 
10. Hedge, V.M., and Anahosur, K.H. (1994): Influence of sowing date of mustard on the epidemiology of white rust. Indian Phytopath., 47, 391 - 394.

11. Kaidan, A.K., and Saharan, G.S. (1983): Symptomatology, host range and assessment of yield losses due to Alternaria brassicae infection in rapeseed and mustard. Indian J Mycol PI Pathol., 13: 319 - 323.

12. Lakra, B.S., and Saharan, G.S. (1989): Location and estimation of oospores of Albugo candida in infected plant parts of mustard. Indian Phytopath., 42, 467.

13. Mehta, N., Singh, K., and Sangwan, M.S. (2008): Assessment of yield losses and evaluation of different varieties/ genotypes of mustard against powdery mildew in Haryana. Plant Dis. Res., 23, 55 - 59.

14. Saharan, G.S. (1992): Management of rapeseed - mustard diseases. In: Kumar D and Rai M (eds.) Advances in oilseed research. Vol. 1 Rapeseed and Mustard Scientific Pub. Jodhpur, pp. 155 - 188.

15. Saharan, G.S., Kaushik, C.D. and Kaushik, J.C. (1988): Sources of resistance and epidemiology of white rust of mustard. Indian Phytopath., 41, 96 - 99.

16. Saharan, G.S., Kaushik, C.D., Gupta, P.P. and Tripathi ,N.N. (1984) : Assessment of losses and control of white rust of mustard. Indian Phytopath., 37, 397.

17. Singh, R.B. and Singh, R.N. (2003): Management of powdery mildew of mustard. Indian Phytopath. , 56, 147150 . 